\section{2 坑道密閉関係}

密閉構築の難易は坑道の状態により左右される実績の平 均值は第 3 表のとおり従来のヅタ密閉に比較して, 期間及 び, 工数ともに縮減した。

\section{3 払肩深坑道維持関係}

払肩, 深道の維持については, 第 4 表のとおり, 坑道仕 繰工数㧍よび払内充てん工数は従来方式に比し若干ではあ るが縮减できた。

3.4 フライアッシュ圧入量の減少

流送充てんの場合の圧入量は, 岩粉袋積袖巻の場合に比
して，第 5 表に示すとおり，上段払では一孔当り $18 \%$ 减， 下段払では $28 \%$ 減となりより少量で効果をあげることが できた。

\section{4. 結言}

以上流送充てんを主体に，当釷に扔ける自然発火防止対 策の概要について述べたが，まだ幾多の解決すべき問題を かかえており，今後さらに研究を進めて行く所存である。

今後とも各方面の御指導をお願いする次第である。

\title{
ガス抜き技術に関する若干の考察 \\ Some Considerations about Methane Drainage Technique
}

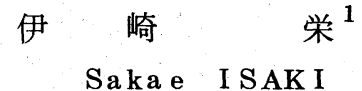

1. 序

ガス抜き技術はガス抜き量を増加させる方法と，その方 法を実施するに当つて必要な保安対策の 2 つに集約される と思われる。ガス抜き量の増加対策の実施は与えられた人員

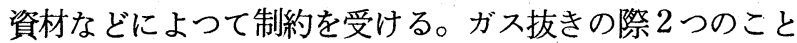
が考えられる。1つは自噴してくるものを吸引すること， 他は吸引寸ればガスが出てくることである。

現在行なつているガス拔きの実体をつかみ，ガス拔き量 を増加させるにはいかなる手段があるか，それを阻害する ものは何かを追及する必要がある。ガス抜き量と負圧，ガ ス拔き量と濃度の関係, ガス拔き量, 負圧, 濃度の関係, およびそれに対する対策について調査研究すべきであろう。 その中のいくつかを試験したのでその結果について述べる。

\section{2. ガス抜き量と負圧の関係}

ガス抜き量と負圧の関係は，吸引負圧を大きくすれば， ガス流量（１００％換算メタン量）は大きくなると一般に 考えられている。その流量は自噴圧のある炭層ガスと岩盤 中に発生した亀裂を通じて流れ込んだ空気と混合され，あ るいは吸引負圧差によって吸引されるガスと混合される。 また両者のくみ合わされたものとに大別できると思われる ので, 坑外, 坑内実験を下記の要領にて実施した。

実験方法は第 1 図のと㧍りで，流体としては圧縮空気を 利用し, 流量値はN T P ( $\left.0^{\circ} 760 \mathrm{mmHg}\right)$ に換算した ロータメータ計測値である。なおルガーによる測定値もほ とんど同じ值を示した。

（1）使用機器の仕様 排気口にエキジスタを設置し，

1. 住友石炭钘業株式会社北海道技術研究所

$950<156>$
$\mathrm{A}$ バルブで吸引負圧を調整し， B $, \mathrm{C}, \mathrm{D}$ バルブで一定の 空気圧を保持させた。負圧測定のため(1)〜 (4)にマノメータを 取付け, 空気流量測定にはロータメータ, ルガー, および サーミスタ風速計を図のように取付け各々測定を行なつた。 Bバルブの開き方をボアホール内の亀裂の大小に置換へ, 流量ガス涌出量に相当するのを変化させ $\mathrm{C} ， \mathrm{D}$ バルブで圧 力調整した。

実験は空気圧の変化（ $0 \sim 5 \mathrm{~kg} / \mathrm{cm}^{2} ）$ または流量ガス 湧出量に相当の変化，亀裂などからの湧出量に相当するも のである。また実験ではー（ B バルブの開き方 $)-(0.1$ $\left.\sim 1.0 \mathrm{~m}^{3} / \mathrm{min}\right)$ による負圧の変化（0２,500 mmAq） とガス吸収引量との関係を求めた。

（2）実験結果 ガス抜き流量，吸収量と負圧の関係。

$\mathrm{B}$ バルブの開きによる流量を $0.1 \sim 1.0 \mathrm{~m}^{3} / \mathrm{min}$ まで変 化，ガス涌出量に相当するときのガス抜き流量と負圧の関 係（ Cバルブを閉じDバルブを開放し， Bバルブで亀裂の 代用の場合）を求めるため $\mathrm{B}$ バルブの開き方を一定に保ち, 吸収負圧を一 $500 \mathrm{mmAq}$ より順次ー $3,500 \mathrm{mmAq}$ まで 変化させ吸収量を測定した。

結果は第 2 図のとおりである。また自噴圧のあるガスを 抜く場合を考穴実験では圧力保持部を $1 \mathrm{~kg} / \mathrm{cm}^{2}$ より 5 $\mathrm{kg} / \mathrm{cm}^{2}$ まで，負圧 ( - $5000 \mathrm{mmAq}$ より $2,500 \mathrm{mmAq}$ まで)と吸収流量との関係を求めた結果変化させたときの一 例を第 3 図に示す。ただし $B$ バルブの開き方は $0.1 \mathrm{~m}^{3} / \mathrm{mi} \mathrm{n}_{\circ}$

（3）坑内実験 自噴圧のあるボアホールに抢ける負圧 と流量の関係の一例を第 1 表に示した。また自噴圧のない あるいは少ないボアホールにおける負圧と流量の関係すな わち層内が擾乱と考えられる場合は第 2 表の通りで負圧の 影響が著しい。 

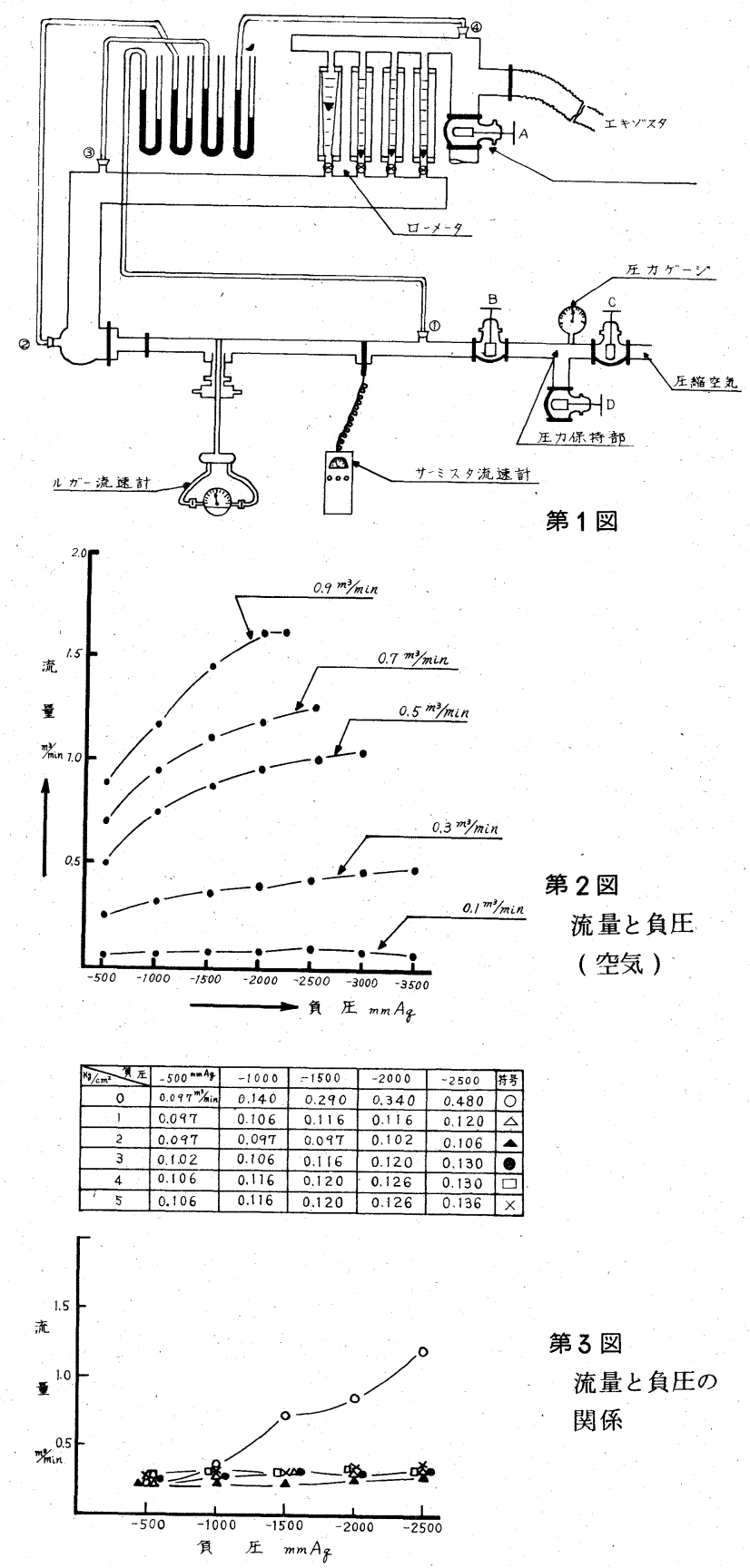

3. 吸引流量 $(100 \%$ 換算値 $)$ と濃度との関係

地下の地圧と岩盤の強度等との関係で発生した亀裂のあ る岩盤中に作孔されると, ボアホールを通じて負圧をかけ てガスを吸引する場合，この亀裂がガス抜きに有利に作用 したり，不利になつたりする。不利になる場合は, 亀裂を 通じて空気を吸入して吸引濃度の低下をきたす時である。 吸引濃度が低下したときの吸引量 ( 純メタン量) に及ぼす 影響, またボアホール内における濃度变化, 濃度低下が地 山ボーリングと払跡ガス抜きに及ぼす影響等について現場 計測を実施した。

\section{1 亀裂の発生状況}

スタンドパイプロ元近くに亀裂が発生すると, ガス吸引 をした場合ガス濃度が低下する。ガスを吸引しながら 2
第 1 表 自噴圧のあるガス拔きボーリンク 1,100 レベル NO. 5 角度一 $40^{\circ}$ ボーリング長 $42.2 \mathrm{~m}$ 口径 $\phi 65 \mathrm{~mm}$ スタンドパイプ長 $14 \mathrm{~m}$

\begin{tabular}{|c|c|c|c|}
\hline 負 圧 & 濃 度 \% & 流量 (純メタン) & 指 数 \\
\hline 自噴のみ & 100 & 1.35 & 100 \\
\hline-500 & 100 & 1.41 & $104(100)$ \\
\hline$-1,000$ & 100 & 1.47 & $108(104)$ \\
\hline$-1,500$ & 100 & 1.50 & $111(106)$ \\
\hline$-1,800$ & 100 & 1.60 & $118(113)$ \\
\hline
\end{tabular}

第 2 表 擾乱ガス抜きボーリング

$-1,110 \mathrm{~L}$ 第 3 立入東 5 \#坑道K座NO. 1 孔 角度 $+40^{\circ}$ ボーリング長 $42.3 \mathrm{~m}$ 口径 $65 \mathrm{~mm}$ スタンドパイブ $24 \mathrm{~m}$

\begin{tabular}{|c|c|c|c|}
\hline 負 圧 & 濃 度 \% & 流量 (純メタン) & 指 数 \\
\hline (自噴のみ)0 & 100 & 0 & \\
\hline-500 & 100 & 1.36 & 100 \\
\hline $\begin{array}{llll}-1, & 0 & 0 & 0\end{array}$ & 100 & 1.84 & 135 \\
\hline$-1,500$ & 100 & 2.08 & 153 \\
\hline$-2,000$ & 100 & \multicolumn{2}{|c|}{ 流速 $20 \mathrm{~m} / \mathrm{sec}$ 以上で $\mathrm{S} \mathrm{O}$} \\
\hline
\end{tabular}

$6 \mathrm{~m}$ おきにガス濃度を測定した。その結果は第 4 図のよう に各孔によつてそれぞれ異なつた濃度勾配を示す。これら の濃度勾配は，採掘の影響，負圧の強さ，コーキングの良 否, 純メタン吸引量, ボアホールの経過時間などに影響さ れ異なつていると思われるが一般的には口元より 11〜18 mの位置よりガス濃度が上昇していることがわかる。

\section{2 濃度亡流量 (純メタン量)}

普通現場ではボアホールの吸引濃度が $30 \%$ 以下になれ ばバルブをとじて吸引を中止する。濃度の低下はガス抜き 孔としての能力がなくなることを意味するかどうかをテス トするため $30 \%$ 以下の吸引停止中のボアホールを選び, 濃度勾配をチェックし, 適当な長さのパイプを再度ボアホ 一ル内に挿入して濃度と吸引量を測定した。その結果の濃 度勾配を第 3 表に，再生後の濃度と吸引量を第 4 表に示す。 (当初のスタンドパイプは 2 in 管, 再挿入管は 1 in 管, コーキング材はウレタンホーム)。表から分るようにスタ

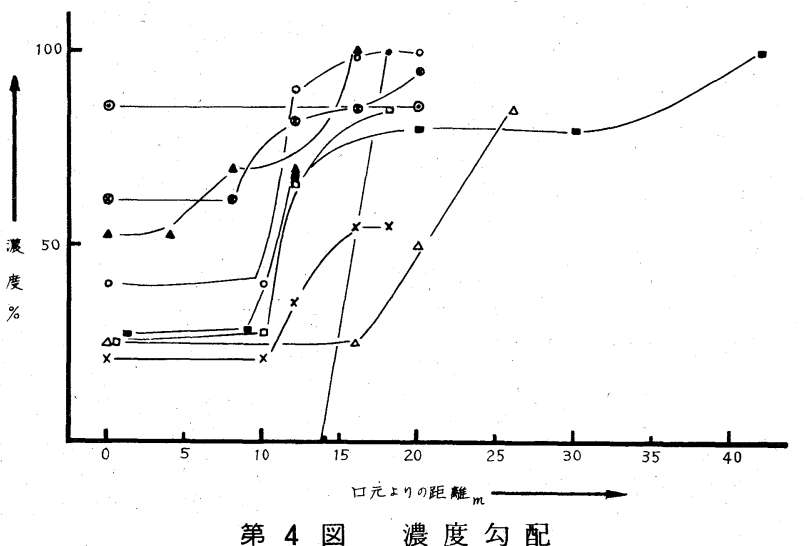

日本鉱業会誌 $/ 87 \quad 1005(' 71-11) \quad 951<157>$ 


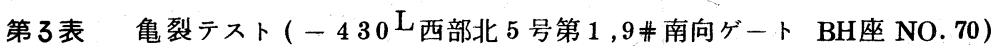

\begin{tabular}{|c|c|c|c|c|c|c|c|c|c|c|c|c|c|c|c|c|}
\hline \multirow{2}{*}{ BH NO. } & \multirow{2}{*}{ 作孔角度 } & \multirow{2}{*}{ 孔長m } & \multirow{2}{*}{$\begin{array}{l}\text { スタンド } \\
\text { ス゚イフ } \\
\text { 長 } \mathrm{m}\end{array}$} & \multirow{2}{*}{$\begin{array}{l}\text { コーキ } \\
\text { ング材 }\end{array}$} & \multirow{2}{*}{ 濃度\% } & \multirow{2}{*}{$\underset{\text { 吸引負圧 }}{(\mathrm{mmHg})}$} & \multicolumn{9}{|c|}{ 亀裂テスト $(\mathrm{m}, \%)$} & \multirow{2}{*}{ 備 } \\
\hline & & & & & & & $0 \mathrm{~m}$ & 6 & 8 & 10 & 12 & 14 & 16 & 18 & 20 & \\
\hline 947 & $+75^{\circ}$ & 81 & 6 & セメント & 21 & 100 & $21 \%$ & 21 & 21 & 21 & 35 & & 56 & 56 & & 孔内崩落 $(18.5 \mathrm{~m}$ ) \\
\hline 948 & $+70^{\circ}$ & 81 & 6 & " & 25 & 191 & 25 & 25 & 25 & 25 & 65 & & & 85 & & \multirow{2}{*}{$\begin{array}{l}\text { 全 上( } 22 \mathrm{~m}) \\
30 \mathrm{~m} 80 \% \\
42 \mathrm{~m} 100 \%\end{array}$} \\
\hline 955 & $+70^{\circ}$ & 65 & 6 & " & 25 & 192 & 25 & 25 & 25 & 25 & 70 & & & & & \\
\hline
\end{tabular}

第 4 表

\begin{tabular}{|c|c|c|c|c|c|c|c|c|c|c|c|c|}
\hline \multirow{2}{*}{ BH NO. } & \multirow{2}{*}{$\begin{array}{l}\text { 再生 } 1 \text { in } \\
\text { ペプ長 } \mathrm{m}\end{array}$} & \multirow{2}{*}{ コーキング材 } & \multicolumn{2}{|c|}{$5 / 16$} & \multicolumn{2}{|c|}{$5 / 31$} & \multicolumn{2}{|c|}{$6 / 11$} & \multicolumn{2}{|c|}{$6 / 18$} & \multicolumn{2}{|c|}{$6 / 20$} \\
\hline & & & 濃度\% & $\mathrm{CH}_{4}$ 量 & 濃 度 & $\mathrm{CH}_{4}$ 量 & 濃 度 & $\mathrm{CH}_{4}$ 量 & 濃 度 & $\mathrm{CH}_{4}$ 量 & 濃 度 & $\mathrm{CH}_{4}$ 量 \\
\hline 947 & 18 & ウレタンホーム & 68 & 0.02 & 51 & 1.05 & 65 & 0.6 & 53 & 0.35 & 53 & 0.8 \\
\hline 948 & 22 & " & 83 & 0.55 & 50 & 0.50 & 56 & 0.25 & 45 & 0.20 & 42 & 0.01 \\
\hline 955 & 20 & " & 50 & 流速なし & 50 & 0.35 & 66 & 0.15 & 62 & 0.10 & 46 & 0.12 \\
\hline
\end{tabular}

ンドパイプを適当な長さまで延長して，濃度を上昇させる ことにより，吸引量を增加させ，また寿命を長くすること ができる。濃度勾配に影響を与える要因は種々あるが，そ れを知ることはガス抜き技術上大切なことであるといえる ( 第 $3 ， 4$ 表のボアホール 3 本は払跡における擾乱ガスを とるためのガス抜きボーリングである)。一方濃度 100 \%で吸引中のガス抜きボアホールに故意に第 5 図のように 漏気させるとメタン吸出量は低下する (第 5 表 )。なお自 噴孔について第 5 図のように漏気させ測定した。空気を漏 気させると濃度は低下し, 混合ガスは增加するがメタン量 は減少しその変化は擾乱ガス抜きボーリングに比べて著し く少ない。

\section{4. ボアホールの性質とスタンドパイプ方式がガ} ス抜きボアホール寿命と吸出量に及ぼす影響

ボアホールのガス吸出量は切羽面のうしろ (払跡) の限 定された範囲のガスの湧出能力, ボアホールの寿命, ボア ホールの直径およびスタンドパイプの種類に左右される。 ボアホールのガス勈出の最適範囲すなわちコーキングの位 置は，ボアホールの全長にわたつてスタンドパイプを挿入 しつつ流量と濃度を測定して得られるので, スタンドパイ

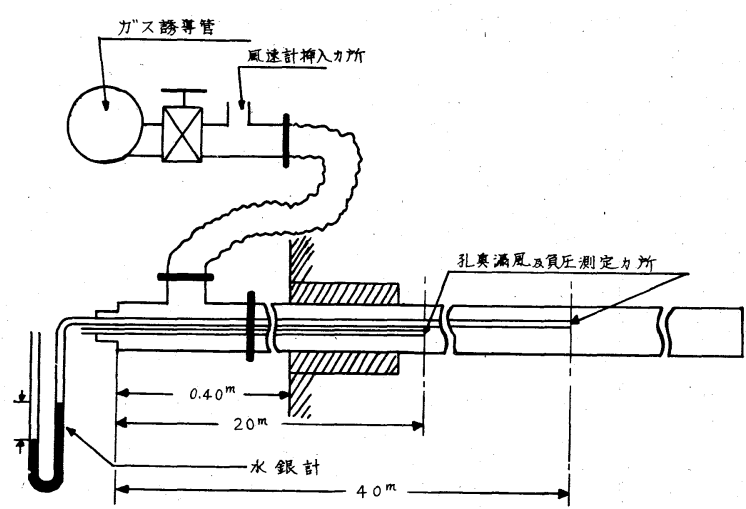

第 5 図漏気テスト
表 5 表 孔奥 $(20 \mathrm{~m})$ 漏気と負圧,濃度, メタン量の関係

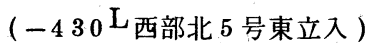

\begin{tabular}{|c|c|c|c|c|c|c|c|c|}
\hline 漏気面積 & $\begin{array}{l}\text { 口元 } \\
\text { 負圧 }\end{array}$ & $\begin{array}{l}\text { 孔奥 } \\
\text { 負圧 }\end{array}$ & $\begin{array}{c}\text { ガス } \\
\text { 濃度 }\end{array}$ & 温度 ${ }^{\circ} \mathrm{C}$ & $\begin{array}{l}\text { 流速 } \\
\mathrm{m} / \mathrm{sec}\end{array}$ & $\begin{array}{l}\text { 混合 } \\
\text { ガス }\end{array}$ & $\mathrm{CH}_{4}{ }^{\text {量 }}$ & $\begin{array}{l}\text { 流量 } \\
\text { 指数 }\end{array}$ \\
\hline $\begin{array}{l}\mathrm{cm} \\
0\end{array}$ & $\begin{array}{c}\mathrm{mmHg} \\
173\end{array}$ & 172 & 100 & & 1.75 & 0.308 & 308 & 100 \\
\hline 0.125 & 173 & 170 & 70 & 20 & 2.10 & 0290 & 0203 & 66 \\
\hline 0.188 & 171 & 169 & 62 & 20 & 2.20 & 0.303 & 0.188 & 61 \\
\hline 0259 & 171 & 169 & 58 & 20 & 2.35 & 0.321 & 0.186 & 60 \\
\hline 1245 & 171 & 169 & 54 & 20 & 2.40 & 0.326 & 0.176 & 57 \\
\hline 2.490 & 171 & 169 & 53 & 20 & 2.40 & 0.326 & 0.172 & 56 \\
\hline
\end{tabular}

プはボアホール内で最大のメタン吸出量を得るような位置 まで扱入し, 通気短絡が少ない所から吸引すべきである。 ガス抜きボアホールからのガス吸出量とスタンドパイプの 長さおよび効果的な負圧との関係はあるボアホールでは吸 引負圧を一 $1,600 \mathrm{mmAq}$ より $800 \mathrm{mmAq}$ に低下させる とガス量が $61.6 \%$ 上昇し, 通気短絡が $41 \%$ 減少してい た。もしガス抜きボアホールの能力を最高に発揮させよう とすれば，それぞれのスタンドパイプは目的の深さまで移 動ができて，かつコーキングは高度の気密性がなければな らぬ。その後がス抜き孔にかかる吸引負圧を調整配分する ことにより, 吸出メタン量と通気短絡が最良の比率になり, ガス抜き量の増量対策につながる。したがつて払跡ガス抜 きボーリングにおけるスタンドパイプの長さは通気短絡を 確実に遮断するためにボーリングする場所と時期及び切羽 面との距離などによつてそれぞれ異なると思われるが少な くとも $15 \sim 20 \mathrm{~m}$ 以上とすべきであり, これ以外にメタ 濃度の高、範聿まで容易に差し込めることが必要である。 気密法は岩盤移動による破壊作用に耐え得る方法でなけれ ばならぬ。また，経済上の理由からスタンドパイプは回収 する方法を選ばなければならぬ。ボアホールの直径につい ては 2 倍にすればガスの涌出面積も 2 倍になり，ガスの流

$952<158>$ 
れによる摩擦損失も減少され，同じ圧力の場合には 7 倍の ガスの通過量が可能となる。特に払跡ガス抜きボーリング のように採掘切羽周辺に作孔される小口径のボーリングは 採掘によつて開放された岩盤移動の影響を強く受けボアホ ールが切断され早く破壊される。したがつて現在ドイッで はガス抜きボーリングロ径 $130 \mathrm{~mm} \phi か ゙$ 実施され， Kor fmann 社の馬力の強い “G BV 152 ”, 作孔機が考 案されている。作孔時間はボアホール口径を $65 \mathrm{~mm}$ めか ら $130 \mathrm{~mm} \phi$ に拡大したにもかかわらず $50 \%$ だけ短か くなり，作孔コストは $40 \%$ 減少させることができたとし ている。第 6 図はボアホール口径 $65 \mathrm{~mm}$ とと $120 \mathrm{~mm} \phi$ と吸引流量の比較表である。

\section{5. む す び}

ガス拔き技術上吸引濃度と負圧は吸引流量に密接な関係 にあつて, とくに濃度はそのボアホールを最高に利用する ための必須条件であり，また作孔口径の大きさも見逃がす

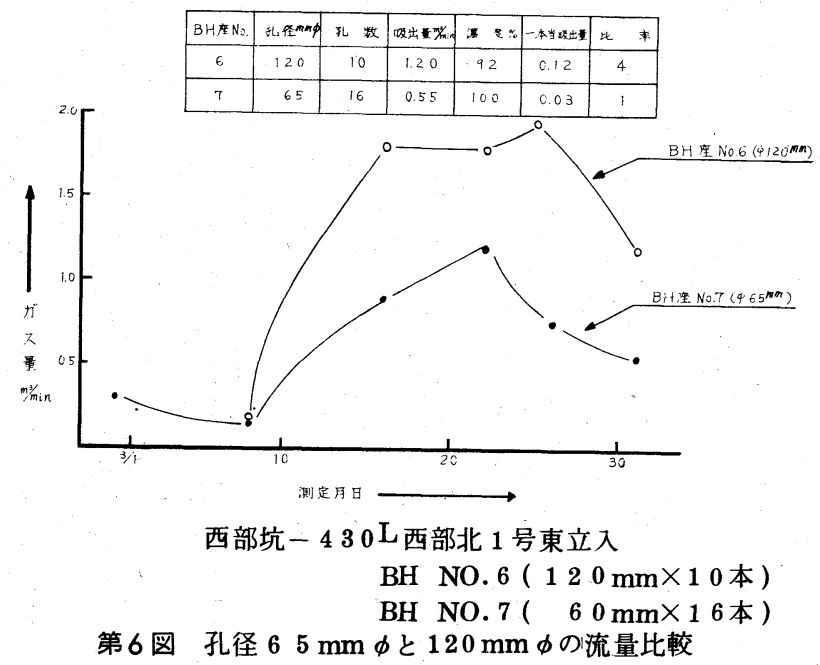

ことのできない問題である。分りにくい点も多々あつたと 思われるが，諸賢の御批判を頂ければ幸と思う。

\section{突出に関する展望と今後の課題}

\section{A View of Gas-outburst and its Future Problems}

$$
\begin{aligned}
& \text { 小田不平次 } \\
& \text { Niheiji ODA }
\end{aligned}
$$

\section{1. 序}

突出は, 普通発生原因, 予知, 抑制の 3 分野について研 究されているが,これら 3 つの分野は互いに密接に関連して いる。それゆえ突出に関係のある事実は，3つの分野に直 接つながつている。

したがつて, 実際に発生している突出は, どんなもので あるのか，またどのような測定值が突出と関係があるのか を把握することを主眼において研究してきた。その結果関 係のありそうな事象を知り得たので，これを基礎にした測 定法が，突出の予知や抑制効果の判定に使用できるか否か， 日常の現場作業の中で試験されている。

さらに突出の発生原因を推定し, 現行の抑制法に考察を 加え，試験し，より有効な抑制法と抑制効果の判定法の開 発をめざしている。

\section{2. 突出に関連があると考えられる事象}

現在まで試験してきた測定法を第 1 表に示す。目的は， 突出を予知する可能性のある方法を得ようとするだけでは なく，突出と少しでも関係のありそうな事象を探すことで あつた。

1. 正会員 住友石炭鉱業株式会社北海道技術研究所
これらの中のいくつかについて述べよう。

一般に切羽面から炭層奥部に向つて作孔されたボアホー ルにおける流出ガス量, ガス圧には, 第 1 図のように，ピ ークがみられる。このピークの位置が切羽面の進行と共に 前後に動いていることが第 2 図よりうかがえる(本測定法 におけるガス圧は，ピークの位置より奥では不明確である)。 図の(6)で発破を掛けた直後に, ガス噴出が発生した。第 3 図に毎発破前後の気流中のガス濃度と, 切羽面より $2 \sim 3$ $\mathrm{m}$ 付近からのガス流出量の変化を示した。図のように気流 中のガス濃度, ガス流出量が低下した後, 突出が発生して いることが多い。このような変化は，石炭の物性か盤圧か どちらかに関係があるように思われたので，まず石炭の物 性をしらべた。ところが室内実験で得られた物性よりも， 切羽面で直接測定したような值，たとえば作孔時の繰粉の

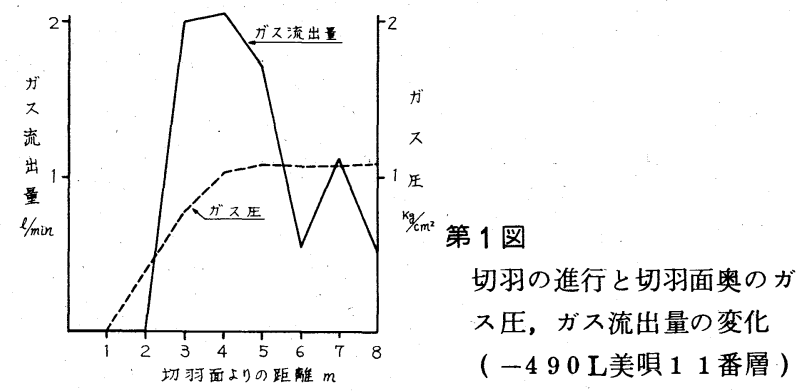

